\title{
Mikozis fungoidesli hastalarda adenozin deaminaz aktivitesinin araștırıması
}

\section{Investigation of adenosine deaminase activity in patients with mycosis fungoides}

\author{
Yılmaz Ulaș, Ayten Ferahbaș*, Cevat Yazıcı**, Demet Kartal* \\ Kayseri Eğitim ve Araștırma Hastanesi, Deri ve Zührevi Hastalıklar Kliniği, Kayseri, Türkiye
}

*Erciyes Üniversitesi Tıp Fakültesi, Deri ve Zührevi Hastalıklar, **Biyokimya ve Klinik Biyokimya Anabilim Dalı, Kayseri, Türkiye

\section{Özet}

Amaç: Mikozis fungoides (MF) derinin T hücreli lenfomasıdır. Primer olarak deride gelişme gösteren malin T hücreler çeşitli klinik bulgulara yol açarlar. Erken dönem mikozis fungoides tanııını koyabilmek klinik ve histopatolojik olarak çoğu zaman zordur. Tanı ve takibinde karşılaşılan zorluklardan en önemlisi; aktivitesini belirtecek özel bir laboratuvar yönteminin olmamasıdır. Adenozin deaminaz (ADA) T lenfosit aktivasyonun özgün olmayan bir göstergesi olarak kabul edilir. Bu çalışmada; MF'li hastalarda plazma ve doku ADA düzeylerinin ölçülmesi ve ADA'nın bu hastalık için bir aktivasyon kriteri olup olmadığının araştıııması amaçlandı.

Gereç ve Yöntem: Çalışmada 40 MF ve 33 kontrol olgusunda spektrofotometrik yöntem kullanılarak plazma ve doku ADA aktiviteleri ölçüldü. Ayrıca hasta grubu içerisinden takipler sonucunda remisyon kriterlerini tamamlayan ve remisyon olarak kabul edilen 17 hastanın bu dönemde değerlendirmeleri yapıldı.

Bulgular: Plazma ve doku ADA düzeyleri MF'li hastalarda kontrol grubuna göre anlamlı derecede yüksek bulundu (sırasıyla, $p<0,001$ ve $p<0,001)$. Remisyondaki 17 hastanın remisyon öncesi plazma ve doku ADA düzeyleri, remisyon dönemi ile karşılaştııılığında istatistiksel olarak anlamlı bir azalma saptandı (sırasıyla, $p<0,001$ ve $p<0,001$ ). Remisyon dönemindeki hastaların doku ADA düzeyi kontrol grubu ile karşılaştııılığında aralarında istatistiksel olarak fark saptanmadı $(p>0,05)$. Ancak remisyondaki hastaların plazma ADA düzeyleri kontrol grubunun plazma ADA düzeylerinden yüksekti ve aralarındaki fark istatistiksel olarak anlamlı idi $(p<0,001)$.

Sonuç: Bizim çalışmamızdaki bu bulgular plazma ve doku ADA düzeylerinin MF'nin aktivitesini yansıtmada değerli olabileceğini desteklemektedir. Ayrıca ADA düzeylerinin ölçümünün hastaların takibinde bir belirteç olarak kullanılabileceği sonucuna varıldı. (Türkderm 2013; 47: 227-31) Anahtar Kelimeler: Adenozin deaminaz, aktivite, mikozis fungoides

\section{Summary}

Background and Design: Mycosis fungoides (MF) is a cutaneous T cell lymphoma. The clinical and histopathological diagnosis of early mycosis fungoides is usually difficult. There is no special laboratory method for the diagnosis of MF and this is the most important problem in diagnosis and follow up the effectiveness of treatment. Adenosine deaminase (ADA) activity is a non-specific marker of T cell activation. In the present study, we aimed to investigate the levels of plasma and tissue ADA in patients with mycosis fungoides and to determine if ADA is an activation criterion for this disease.

Materials and Methods: The levels of ADA activities in both plasma and tissue were spectrophotometrically measured in 40 patients with MF and compared to those of 33 healthy subjects. Moreover, a subgroup analysis regarding ADA activities was performed in 17 patients who achieved complete remission after different kinds of treatments.

Results: Patients with MF had more significantly elevated plasma and tissue ADA activity levels than those of controls $(p<0.001$ and $p<0.001)$.

Yazışma Adresi/Address for Correspondence: Dr. Yılmaz Ulaş, Kayseri Eğitim ve Araştırma Hastanesi, Deri ve Zührevi Hastalıklar Kliniği, Kayseri, Türkiye E-posta: yilmazulas@erciyes.edu.tr Geliş Tarihi/Received: 01.12.2012 Kabul Tarihi/Accepted: 15.02.2013

Türkderm-Deri Hastalıkları ve Frengi Arșivi Dergisi, Galenos Yayınevi tarafından basılmıștır.

Turkderm-Archives of the Turkish Dermatology and Venerology, published by Galenos Publishing. 
There was a statistically significant decrease in the plasma and tissue ADA activity levels after remission when compared to initial values in 17 patients revealing complete remission $(p<0.001$ and $p<0.001$, respectively). While there was no statistically significant difference between MF patients in remission and controls in respect to tissue ADA activities ( $p>0.05$ ); MF patients in remission were found to have higher plasma levels of ADA activities than those of controls ( $<<0.001$ ).

Conclusion: The findings of this study may provide an important clinical support for showing the roles of plasma and tissue ADA activity levels to predict disease activity in MF patients. In addition, levels of ADA activity measurements might be a marker in follow-up of MF patients. (Turkderm 2013; 47: 227-31)

Key Words: Adenosine deaminase, activity, mycosis fungoides

\section{Giriş}

Mikozis fungoides (MF) T lenfositlerin malin proliferasyonu ve bu proliferasyonun deriyi infiltre etmesi ile karakterize en sık gözlenen primer $T$ hücreli lenfomadır ${ }^{1}$. Adenozin deaminaz (ADA), pürin nükleotidlerinin katobolizmasında rol oynayan, adenozin ve deoksiadenozini geri dönüşümsüz olarak inozin ve deoksiinozine dönüşümünü katalize eden bir enzimdir. Bu enzim, lenfositlerin, özelikle $\mathrm{T}$ lenfositlerin farklılaşmasında ve proliferasyonunda önemli rol oynamakta ve $T$ hücre aktivasyonunun ve hücresel immünitenin nonspesifik bir belirteci olarak kabul edilmektedir2,3.

MF olgularında ADA aktivitesi ile ilgili literatürde çok fazla sayıda çalışma bulunmamaktadır. Daha önceden yapılan çalışmalarda MF'de sadece serumda ADA aktivitesi çalışılmıştır. Normal epidermiste ADA aktivitesi göreceli olarak düşüktür ancak deri hastalıklarındaki enzim aktivitesinin varlığı tam olarak bilinmemektedir. Daha önceden yapılan çalışmalarda psoriaziste ve skuamöz hücreli karsinomda epidermiste ADA aktivitesinin arttığı gösterilmiş ve yüksek ADA aktivitesi belirgin DNA sentezinin artışını gösteren epidermal keratinositlerin hiperproliferasyonu ile uyumlu olduğu düşünülmüştür4-6.

Bu çalışmada T lenfosit aktivasyonun özgün olmayan bir göstergesi olarak kabul edilen ADA'nın hastalık aktivasyonu, tedavi yanıtı ve hastalık takibinde kullanılabilecek bir belirteç olabileceği düşünülerek MF'li hastalarda plazma ve doku ADA düzeylerinin değerlendirilmesi amaçlandı.

\section{Gereç ve Yöntem}

Erciyes Üniversitesi Tıp Fakültesi Dermatoloji Anabilim Dalı ve Hematoloji Bilim dalına başvuran ve/veya takip ve tedavileri yapılmakta olan çeşitli evrelerdeki MF'li hastalar çalışma grubunu oluşturdu. Çalışma Üniversite Etik Kurulu tarafından onaylandı ve tüm hastalardan veya hasta velilerinden bilgilendirilmiş gönüllü olur formu alındı.

Klinik ve histopatolojik olarak MF tanısı alan tüberküloz, tifo, infeksiyöz mononükleoz, sarkoidoz, bruselloz, psoriazis, Behçet hastalığı, romatoid artrit, kronik karaciğer hastalığı gibi daha önceden bilinen ve serum ADA düzeylerini etkileyen başka bir hastalığı olmayan 19'u erkek, 21'i kadın toplam 40 hasta çalışmaya alındı. Takipler sonucunda remisyon kriterlerini tamamlayan 17 hastanın bu dönemde de değerlendirmeleri yapıldı.

Kontrol grubu ise Ortopedi Kliniği'inde akut travma nedeniyle ekstremite ampütasyonu yapılan ve 16'sı erkek, 17'si kadın 33 hastadan oluşturuldu. Hasta grubu için tanımlanmış çalışmaya alınmama kriterlerine sahip olan ve yumuşak doku veya kemik tümörü nedeniyle ampütasyon yapılan, ödem ve egzama gibi deride ikincil değişikliği olan hastalar çalışmaya alınmadı.

Çalışmaya dâhil edilen tüm hastaların yaşı, cinsiyeti, mesleği, hastalık süresi, aile hikâyesi ve varsa diğer hastalıkları kaydedildi. Etkilenen vücut yüzeyi yüzdelik olarak hesaplandı, deri biyopsisinden 2 hafta önce tüm tedaviler kesildi. Deri biyopsileri ile rutin histopatolojik inceleme ve immunfenotipleme yapılarak tanıları doğrulandı. Tüm hastaların TNM klasifikasyonu ile evrelendirmeleri yapıldı. Uygulanan tedaviler ile klinik, histopatolojik ve laboratuvar olarak hastanın deri lezyonlarında tam kaybolma, gösterilebilir lenf nodu, periferik kan ve iç organ tutulumu olmadığı zaman hastalar remisyona girmiş olarak kabul edildi.

Çalışmaya dahil edilen 40 hastanın başlangıçta bir kez ve bunlar içinden remisyona girenlerden ise remisyonda ikinci kez, kontrol grubundan ise bir kez tek kullanımlık enjektör ile 10 ml EDTA'lı venöz kan örneği alındı. Kanlar 5000 devir/dakika hızında 10 dakika santrifüj edilerek plazma süspansiyonları elde edildi. Plazma süspansiyonları eppendorf tüplerine aktarılarak çalışma gününe kadar -70 o C'de saklandı.

Doku örnekleri hastalardan tedavi öncesi lezyonlu bölgeden, remisyon döneminde ise ilk biyopsi alanına yakın bölgeden olmak üzere 2X1 $\mathrm{cm}$ 'lik insizyonel biyopsi olarak alındı. Alınan doku örnekleri serum fizyolojik ile üç kez yıkandı, tartıldı ve eppendorf tüpler içerisinde çalışma gününe kadar -70 o $C^{\prime}$ de saklandı. Kontrol grubundaki hastalardan operasyon sırasında ampüte yara dudaklarından $2 \times 1$ cm'lik sağlam doku örnekleri alındı ve hasta grubunun örneklerine benzer şekilde saklandı.

Hastalığın evresi, klinik bulgular, hastanın yaşı ve genel durumuna göre hastalara uygun tedavi başlanıldı. Erken evre hastalarda 1. basamak tedavi olarak öncelikle; yama dönemi ve vücut tutulum oranı \%10'dan daha az olan hastalara topikal potent kortikosteroidler tek başına veya birlikte geniş band UVB veya dar band UVB tedavisi, vücut tutulum oran \%10 dan fazla olan yama evresinde olanlar için öncelikle UVB (dar veya geniş band) veya plak aşamasında PUVA tedavisi uygulandı. Tedaviye yeterli yanıt alınamayan hastalarda 2. basamak olarak interferon alfa tek başına veya PUVA/UVB tedavisine sistemik interferon alfa veya retinoidler eklendi.

Hasta ve kontrol grubunun plazma ve homojenize doku ADA düzeyleri Giusti ve Galanti7 tarafından tanımlanan yönteme göre belirlendi.

İstatistiksel değerlendirmeler SPSS 15.00 (Statistical Packages for Social Sciences; SPSS Inc., Chicago, Illinois, USA) kullanılarak yapıldı. İki nitel değişkenin karşılaştırılmasında Ki-kare testi kullanıldı. İki grup karşılaştırılmalarında veriler normal dağılım gösteriyorsa iki örnek t testi, veriler normal dağıım göstermiyorsa Mann Whitney U testi kullanıldı. Bağımlı iki grup karşılaştırmalarında veriler normal dağılım gösteriyorsa Bağımlı iki örnek t testi, veriler normal dağılım göstermiyorsa Wilcoxon t testi kullanıldı. Iki nicel değişkenin karşılaştırılmasında veriler normal dağılım gösteriyorsa Pearson Korelasyon Analizi, veriler normal dağılım göstermiyorsa Spearman Korelasyon Analizi kullanıldı. P değeri <0,05 istatistiksel olarak anlamlı kabul edildi.

\section{Bulgular}

Çalışmaya alınan MF'li hastaların yaşları 11-75 yıl, kontrol grubunun yaşları ise 17-79 yıl arasında idi. Hastaların $19(\% 47,5)^{\prime}$ u erkek, 21 $(\% 52,5)^{\prime}$ i kadındı. Kontrol grubunun ise $16(\% 48,5)$ 'sı erkek, 17 
$(\% 51,5)$ 'si kadındı. Hasta ve kontrol grubunun yaş ortalamas ve cinsiyetleri karşılaştırıldığında istatistiksel olarak anlamlı fark bulunamadı $(p>0,05)$

Hastalık süreleri erkeklerde $65 \pm 70,14$ ay, kadınlarda $99,19 \pm 112,47$ ay olup, ortalama $82,95 \pm 95,17$ ay idi.

Çalışmaya dahil edilen 40 MF olgusunun 21'i evre IA, 12'si evre IB ve 7'si evre IIA olup daha ileri evreli hastamız bulunmamakta idi

Deri tutulum oranları karşılaştırıldığında 21 (\%52,5) hasta T1, $19(\% 47,5)$ hasta T2 evresindeydi. T3 ve T4 evreli hastamı bulunmamaktaydı.

Çalışmanın başında 40 MF'li hastanın tümünden, takiplerde ise remisyona girmiş olarak kabul edilen 17 hastadan plazma ve doku ADA düzeyleri ölçülüp, kontrol grubunun plazma ve doku ADA düzeyleri ile karşılaştırıldı. Aktif hastalığı bulunan $40 \mathrm{MF}$ hastasının plazma ADA düzeyi $21,54 \pm 2,36 \mathrm{U} / \mathrm{L}$, doku ADA düzeyi ise $3,50 \pm 0,83$ $\mathrm{U} / \mathrm{mg}$ protein ve kontrol grubunun plazma ve doku ADA düzeyleri sırasıyla $12,39 \pm 3,02 \mathrm{U} / \mathrm{L}$ ve $2,17 \pm 0,82 \mathrm{U} / \mathrm{mg}$ protein bulundu. Kırk hastanın başlangıç plazma ve doku ADA düzeyleri kontrol grubunun plazma ve doku ADA düzeylerinden yüksekti ve aralarında istatistiksel olarak anlamlı bir fark mevcuttu (sırasılya, $p=0,0001$ ve $p=0,0001$ ). Hasta ve kontrol grubuna ait klinik özellikleri ve ADA düzeyleri tabloda özetlenmektedir.

Takipler sonucu remisyona giren 17 hastanın remisyondaki değerleri remisyon öncesiyle ve kontrol grubunun değerleri ile karşılaştıııldı.

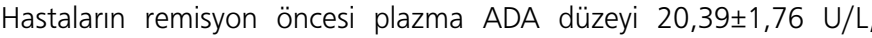
doku ADA düzeyi ise $3,62 \pm 0,72 \mathrm{U} / \mathrm{mg}$ protein ve remisyondaki hastaların plazma ve doku ADA düzeyleri sırasıyla 17,99 $1,32 \mathrm{U} / \mathrm{L}$ ve $1,99 \pm 0,25 \mathrm{U} / \mathrm{mg}$ protein bulundu. Hastaların remisyon öncesi plazma ve doku ADA düzeyleri remisyon dönemindeki plazma ve doku ADA düzeylerine göre yüksekti ve aralarındaki fark istatistiksel olarak anlamlı idi $(p<0,001)$. Hastaların remisyon öncesi ve remisyon döneminde plazma ADA düzeyleri kontrol grubunun plazma ADA düzeylerinden yüksekti ve aralarındaki fark istatistiksel olarak anlamlı idi $(p<0,001)$. Remisyon öncesi hastaların doku ADA düzeyleri kontrol grubuna göre anlamlı olarak yüksek iken $(p<0,001)$, remisyon döneminde doku ADA düzeyi kontrol grubu ile karşılaştırıldığında aralarında anlamlı farklıık yoktu $(p>0,05)$. Hastalardaki ortalama remisyon süresi 4,65 (4-35) ay

Tablo 1. Hasta ve kontrol grubuna ait klinik özellikleri ve ADA düzeyleri

\begin{tabular}{|l|l|l|}
\hline & Hasta grubu & Kontrol grubu \\
\hline Yaş (ort $\pm S S^{*}$ ), yıl & $46,30 \pm 13,91$ & $38,67 \pm 20,20$ \\
\hline Cinsiyet (E/K) & $19 / 21$ & $16 / 17$ \\
\hline Hastalık süresi, ay & $82,95 \pm 95,17$ & \\
\hline Evre IA & 21 & \\
Evre IB & 12 & \\
Evre IIA & 7 & \\
\hline T1** & 21 & \\
T2*** & 19 & $12,39 \pm 3,02$ \\
\hline $\begin{array}{l}\text { Plazma ADA U/L } \\
\text { Doku ADA U/mg }\end{array}$ & $21,54 \pm 2,36$ & $2,17 \pm 0,82$ \\
protein & $3,50 \pm 0,83$ & \\
\hline
\end{tabular}

* SS: Standart sapma

** T1: Deri tutulum oranı \%10' dan az

$\star \star \star T 2$ : Deri tutulum oranı \%10' dan fazla olup, remisyon dönemi plazma ve doku ADA düzeylerindeki azalma ile remisyon süreleri arasında istatistiksel olarak anlamlı bir korelasyon saptanmadı $(p>0,05)$ (Şekil 1,2).

Hastaların başlangıç evrelerine göre plazma ve doku ADA düzeyleri incelendiğinde tüm evreler arasında plazma ve doku ADA düzeyleri arasında istatistiksel olarak anlamlı bir fark bulunamadı $(p>0,05)$.

Hastaların vücut tutulum oranına göre plazma ve doku ADA düzeyleri değerlendirildiğinde; T1'de plazma ve doku ADA düzeyleri sırasıyla $21,91 \pm 2,34 \mathrm{U} / \mathrm{L}$ ve $3,46 \pm 0,84 \mathrm{U} / \mathrm{mg}$ protein, $\mathrm{T} 2$ ' de plazma ve doku ADA düzeyleri sırasıyla $21,13 \pm 2,34 \mathrm{U} / \mathrm{L}$ ve $3,56 \pm 0,85 \mathrm{U} / \mathrm{mg}$ protein bulundu. T1 ve T2 evreler arasında doku ve plazma ADA düzeyleri açısından istatistiksel olarak bir fark yoktu $(p>0,05)$.

Ayrıca hastalık süreleri ile plazma ve doku ADA düzeyleri karşılaştırıldığında aralarında istatistiksel olarak anlamlı bir fark bulunamadı $(p>0,05)$. Cinsiyetler arası plazma ve doku ADA düzeyleri karşılaştırıldığında ise istatistiksel olarak anlamlı fark yoktu.

\section{Tartışma}

Malin ve benin pek çok hastalıkta ADA aktivitesini inceleyen çalışmalar yapılmıştır. T hücrelerinin aktif olarak yer aldığı bir çok hastalıkta ADA düzeyleri artmaktadır. Tüberküloz, tifoid ateş, infeksiyöz mononükleoz, hepatit, akut lenfoblastik lösemi, pnömoni, romatoid artrit, sistemik lupus eritematozus, psoriazis ve Behçet hastalığı gibi serum ADA düzeyini yüksek olarak rapor eden çeşitli çalışmalar bulunmaktadır6,8-10. Bizim çalışmamızda olguları seçerken plazma ve doku ADA düzeyini etkileyebilecek başka bir hastalığın olmamasına dikkat edildi.

ADA ayrıca bir çok lenfoproliferatif hastalıkta da çalışılmıştır. Özellikle T hücre kaynaklı tümörlerde yüksek ADA aktivitesi bildirilmiştir. İnsan lösemi hücrelerinde ölçülen yükselmiş ADA düzeyleri malin hücrelerde

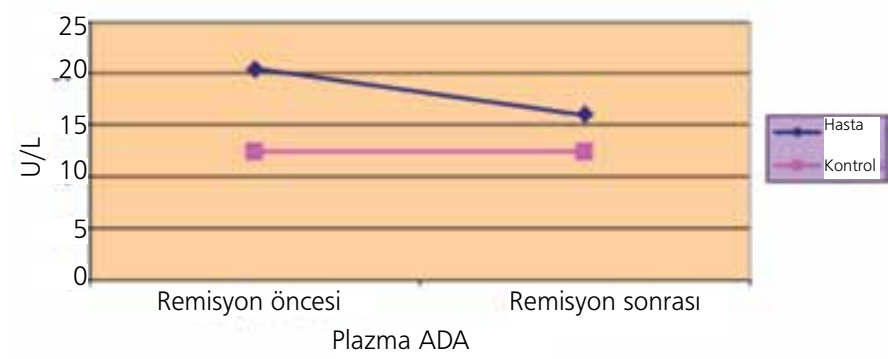

Şekil 1. Remisyon öncesi ve sonrası plazma ADA düzeyinin kontrol grubuna göre karşılaştırılması

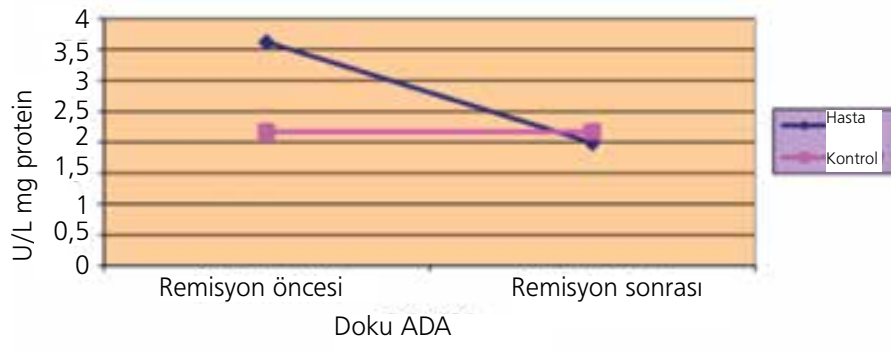

Şekil 2. Remisyon öncesi ve sonrası doku ADA düzeyinin kontrol grubuna göre karşılaştırılması 
artan metabolik aktivite sonucu oluşan adenozinin ve adenozin nükleotidlerinin potansiyel olarak toksik birikimini önlemeye yönelik bir detoksifikasyon mekanizması olduğu öne sürülmektedir. Alternatif olarak, hızlanmış metabolizmaya sahip malin lenfosit hücrelerinin yeni DNA sentezi için ihtiyaçları olan pürin nükleotidlerini en kısa zamanda ve en az enerji harcayarak tekrar elde edebilmek için birçok enzimin rol oynadığı nükleotid yapım yollarını aktive ettikleri bilinmektedir. ADA'nın da bir pürin kurtarma yolu enzimi olduğuna inanılmaktadır. ADA aktivitesinin, pürin kurtarma yolu ile gerekli nükleotid ihtiyacın karşılamak için artmış olabileceği düşünülmektedir. Sonuç olarak bu iki görüş aktive lenfositlerde artmış olan ADA düzeyinin nedenleri olabilir11-13.

Koizumi ve ark.4, 1992 yılında yayınladıkları bir çalışmada psoriazisli, MF'li ve $T$ hücre lösemili hasta grubunda serum ADA aktivitesini ölçmüşler, MF ve T hücre lösemili hasta grubunda yüksek bulurken, psoriazisli hasta grubunda normal bulmuşlardır. Ancak bu çalışmada kontrol grubu olmadığı için sonuçların güvenirliliği azalmıştır. Bu bizim çalışmamızda kontrol grubu ile karşılaştırıldığında hasta grubundaki plazma ADA yüksekliği istatistiksel olarak anlamlı olarak saptanmıştır. Koizumi ve ark. ${ }^{11}, 1993$ yılında yayınladıkları ikinci bir çalışmada ise, farklı evrelerdeki (IB, IIB, III ve IVB) 15 MF'li hastanın serum ADA aktivitelerini araştırmışlardır. Hastaların serum ADA düzeylerinin sağlıklı kontrollere göre istatistiksel olarak anlamlı derecede yüksek olduğunu bulmuşlar, ayrıca tümör evresinde organ tutulumu olan iki hastanın son derece yüksek ADA aktivitesine sahip olduğunu tespit etmişler ve serumda ADA aktivitesinin evrenin ilerlemesi ile daha yüksek hale geldiğini belirtmişlerdir. Çalışmada serum ADA aktivitesi ölçümünün MF progresyonunun güvenilir bir göstergesi olduğu sonucuna varılmıştır. Ülkemizde Yalçın ve arkadaşlarının ${ }^{14}$, yapmış olduğu bir çalışmada farklı evrelerdeki MF'li hastalar ile kontrol grubunun serum ADA düzeyleri arasında fark olmadığı ve serum ADA aktivitesinin ölçümünün hastalığın takibinde diagnostik veya prognostik bir belirteç olarak kullanılamayacağı sonucuna varmışlardır.

Çalışmamızda ise başlangıçta aktif hastalığı bulunan 40 MF'li hastayla kontrol olarak alınan ve MF olmayan 33 olgu karşılaştıııldı. Hastalarımızın başlangıç plazma ADA düzeyleri kontrol grubuna göre istatistiksel olarak anlamlı oranda yüksekti. Bu bulgu daha önceki literatür bilgileri ile uyumlu bulundu4,11. Bu çalışmanın diğer çalışmalardan farkı remisyona giren hastaların değerlendirilmesi idi. MF'li 40 hastamızdan 17'si ortalama 14,65 ay sonra remisyona girmiş olarak kabul edildi. Hastaların remisyon döneminde plazma ve doku ADA düzeyleri remisyon öncesi değerlere göre istatistiksel olarak anlamlı derecede azaldı. Remisyon dönemindeki değerler kontrol grubu ile karşılaştırdığında ise doku ADA düzeyi anlamlı olarak azaldı ve kontrol grubu doku ADA düzeyleri ile aralarında istatistiksel olarak fark yoktu. Fakat remisyonda plazma ADA düzeyi remisyon öncesi döneme göre anlamlı derecede düşmesine rağmen, kontrol grubunun plazma ADA düzeylerine göre hala yüksekti (Şekil 1,2).

Çalışmamızda remisyon döneminde devam eden plazma ADA düzeyi yüksekliğin nedeni olarak, klinik ve laboratuvar olarak deri, lenf nodu ve periferik kanda gösteremediğimiz malin $\mathrm{T}$ lenfositlerinden kaynaklanabileceği düşünüldü. Bu amaçla daha önceki literatürler incelendiğinde yapılan çeşitli çalışmalarda MF tanılı hastaların normal görünüşlü, lezyonsuz deri bölgelerinden yapılan histopatolojik incelemede malin T lenfositlerin varlığı gösterilmiştir. ìlk defa 1987 yılında Braverman ve ark. ${ }^{15}$, tedavi sonrası klinik olarak lezyonları kaybolmuş dokuz MF hastasının normal görünüşlü deri bölgelerinden alınan biyopsilerinin elektron mikroskopik incelemesinde; epidermiste birkaç 'MF hücresi' tespit etmişlerdir. Ayrıca araştırmacılar bu bulgunun sağlıklı kişilerin derilerinde gözlemlenmediğini bildirmiştir. Yakın bir zamanda El-Darouti ve ark. ${ }^{16}$, yapmış olduğu bir çalışmada ise; yama ve/veya plak lezyonları bulunan 30 erken evre MF hastasının normal görünüşlü, lezyonsuz deri bölgelerinin histopatolojik incelemesinde hastaların \%70'in de MF'nin klasik histopatolojik bulgularını gösteren dermal infiltrat ve epidermotopizm bulmuşlardır. Aynı çalışmada sağlıklı kontrollerin deri biyopsilerinin histopatolojik incelemesinde ise hiçbirinde epidermotropizme rastlanılmamıştır. Ayrıca son yıllarda PCR ile yapılan çalışmalarda erken evre MF hastalarının ortalama \%50'sinde periferik kanlarında deride neoplastik $T$ lenfositlerle uyumlu olan $T$ hücre klonları saptanmıştır ${ }^{17,18}$. Erken dönemde periferik kanda tespit edilen bu hücrelerin derideki neoplastik lenfositlerden kaynaklandığ düşünülmüştür.

$\mathrm{Bu}$ çalışmalar ışığında remisyondaki hastaların remisyon öncesi doğrudan deriye yönelik uygulanan (topikal kortikostroidler, fototerapi gibi) tedaviler ile doku ADA düzeyi beklenen seviyeye düşmesine rağmen, bu tedavilerin periferik kana etki etmemesinden dolayı plazma ADA düzeylerinde istenilen düşüşün görülememiş olabileceği sonucuna varıldı. Ayrıca remisyon öncesine göre remisyondaki hastaların plazma ADA düzeyindeki azalma ise derideki neoplastik lenfositlerin tedavi ile gerilemesi sonucu periferik kana geçen lenfositlerin azalmasına bağlı olabileceği düşünüldü.

$\mathrm{Bu}$ nedenlerle, uygulanan tedaviler ile klinik, histopatolojik ve laboratuvar olarak hastanın tüm deri lezyonlarının kaybolduğu, gösterilebilir lenf nodu ve visseral organ tutulumu olmadığı kanıtlansa dahi lezyonsuz normal deride ve periferik kandaki olması muhtemel neoplastik lenfositlerin varlığı dolaşımdaki ADA'nın kaynağı olabilir. Bu yönden plazma ADA ölçümünün hastalık takibinde, remisyona karar vermede ve kalan tümör yükünü göstermede değerli olabileceği ve böylece bunun sonucunda ADA'nın remisyonu gösteren bir belirteç olarak kullanılabileceği düşünüldü.

Çalışmamızda evreler arası plazma ve doku ADA düzeyleri araştırıldı. Evreler arasında ADA düzeylerinde istatistiksel olarak anlamlı fark bulunmadı. Bunun tüm hastaların erken evrede ve lezyonların deriye sınırlı olmasından kaynaklandığı düşünüldü. Ayrıca hastaların vücut tutulum oranına göre plazma ve doku ADA düzeyi değerlendirildiğinde; lezyonların yaygınlığı ile ADA düzeyi arasında istatistiksel olarak anlamlı bir ilişki bulunamadı. Bunun nedeninin çalışmamızda tümör ve eritrodermi gibi ileri evreli hastamız yoktu ve hastaların tümü T1 ve T2 evresinde idi. Ayrıca istatistiksel karşılaştırma için T1 ve T2 evrelerindeki hasta sayılarının yeterli olmamasından kaynaklanabileceği düşünüldü. Bu çalışmada hastaların yaşları, cinsiyetleri ve hastalık süreleriyle ADA düzeyleri arasında ilişki değerlendirildi ancak bir korelasyon saptanamadı. Bu sonuç MF'li hastalardaki ADA düzeylerinin hastaların yaşlarından, cinsiyetlerinden ve hastalık sürelerinden etkilenmediğini göstermektir.

Çalışmanın sonucunda MF hastalarının plazma ve doku ADA değerleri kontrol grubuna göre çok yüksek olduğu, uygulanan tedaviler ile ADA değerlerinin düştüğü saptandı. Remisyona giren hastalarda özellikle doku ADA aktiviteleri tedavi sonrası istatistiksel olarak anlamlı derecede azaldı. Bu sonuçlar ile ADA düzeylerinin MF'nin aktivitesinin değerlendirilmesinde oldukça önemli bir parametre olabileceği ve hastalığın takibinde bir belirteç olarak kullanılabileceği sonucuna varıldı. 


\section{Kaynaklar}

1. Panda S: Mycosis fungoides: Current trends in diagnosis and management. Indian J Dermatol 2007:52:5-20.

2. Canpolat F, Unver M, Eskioğlu F, Kösebalaban S, Durmazlar SP: Serum and erythrocyte adenosine deaminase activities in patients with Behçet's disease. Int J Dermatol 2006;45:1053-6.

3. Gopi A, Madhavan SM, Sharma SK, Sahn SA: Diagnosis and treatment of tuberculous pleural effusion in 2006. Chest 2007;131:880-9.

4. Koizumi H, Ohkawara A: Adenosine deaminase activity in sera of patients with psoriasis, mycosis fungoides and adult T cell leukemia. Acta Derm Venereol 1992;72:410-2.

5. Koizumi H, lizuka H, Aoyagi T, Miura Y: Characterization of adenosine deaminase from normal human epidermis and squamous cell carcinoma of the skin. J Invest Dermatol 1985;84:199-202.

6. Köse K, Utaş S, Yazici C, Akdaş A, Keleştimur F: Effect of propylthiouracil on adenosine deaminase activity and thyroid function in patients with psoriasis. Br J Dermatol 2001;144:1121-6.

7. Giusti G, Galanti B: Colorimetric method. Adenosine deaminase. Methods of enzymatic Analysis. Ed. Bergmeyer HU. , 3rd edition, Weinheim, Verlag chemie, 1984;315-23.

8. Ungerer JP, Oosthuizen HM, Bissbort SH, Vermaak WJ: Serum adenosine deaminase: isoenzymes and diagnostic application. Clin Chem 1992;38:1322-6.

9. Khosla SN, Kumar D, Singh V: Lymphocytic adenosine deaminase activity in typhoid fevers. Postgrad Med J 1992;68:268-71.
10. Taysi S, Polat MF, Sari RA, Bakan E: Serum adenosine deaminase and cytidine deaminase activities in patients with systemic lupus erythematosus. Clin Chem Lab Med 2002;40:493-5.

11. Koizumi H, Tomizawa K, Tanaka H, Kumakiri M, Ohkawara A: Clinical significance of serum adenosine deaminase activity in patients with mycosis fungoides. J Dermatol 1993;20:394-9.

12. Morisaki T, Fujii H, Miwa S: Adenosine deaminase (ADA) in leukemia: Clinical value of plasma ADA activity and characterization of leukemic cell ADA. Am J Hematol 1985;19:37-45.

13. Saraçoğlu U, Güven $O$, Durak i: Ağız kanserli hastaların tükürüklerindeki adenozin deaminaz (ADA) aktiviteleri. T Klin Diş Hek Bil 2003;9:42-6.

14. Yalcin B, Sahin S, Ciliv G: Normal serum adenosine deaminase activity in mycosis fungoides. Acta Derm Venereol 1997;77:403-4.

15. Braverman IM, Klein S, Grant A: Electron microscopic and immunolabeling studies of the lesional and normal skin of patients with mycosis fungoides treated by total body electron beam irradiation. J Am Acad Dermatol 1987;16:61-74.

16. El-Darouti MA, Marzouk SA, Bosseila M, et al: Microscopic study of normal skin in cases of mycosis fungoides. Int J Dermatol 2006;45:1043-6.

17. Fraser-Andrews EA, Woolford AJ, Russell-Jones R, Seed PT, Whittaker SJ: Detection of a peripheral blood $T$ cell clone is an independent prognostic marker in mycosis fungoides. J Invest Dermatol 2000;114:117-21.

18. Muche JM, Lukowsky A, Asadullah K, Gellrich S, Sterry W: Demonstration of frequent occurrence of clonal $T$ cells in the peripheral blood of patients with primary cutaneous T-cell lymphoma. Blood 1997;90:1636-42. 